\title{
ACERCA DE COOPERAÇÃO INTERNACIONAL CIENTÍFICA E TECNOLÓGICA SUL-SUL PARA PROMOVER AS ESTRATÉGIAS DE GESTÃO E REDUÇÃO DE DESASTRES DA UNASUL E CELAC. UMA PROPOSTA DE PLANO ENTRE AS REGIÕES AMÉRICA DO SUL E ÁSIA-PACÍFICO.
}

\section{ABOUT SOUTH-SOUTH INTERNATIONAL SCIENTIFIC AND TECHNOLOGICAL COOPERATION TO ENHANCE UNASUR AND CELAC DISASTER RISKS MANAGEMENT AND REDUCTION STRATEGIES. A PROPOSAL PLAN FOR SOUTH AMERICA AND ASIA-PACIFIC REGIONS.}

\section{ACERCA DE LA COOPERACIÓN INTERNACIONAL CIENTÍFICA Y TECNOLÓGICA SUR-SUR PARA MEJORAR LAS ESTRATEGIAS DE UNASUR Y LA CELAC EN GESTIÓN Y REDUCCIÓN DE DESASTRES. UNA PROPUESTA DE PLAN ENTRE LAS REGIONES DE AMÉRICA DEL SUR Y ASIA-PACÍFICO.}

Ronaldo Lyrio BORGO ${ }^{1}$

RESUMO: A gestão de risco de desastres e políticas de redução, as estratégias e iniciativas políticas tradicionais intergovernamentais na América do Sul, América Latina e Caribe estão realmente progredindo fortemente. As regiões abraçam todas as iniciativas implementadas durante o último século, e, decisivamente avançam para criar mecanismos e recursos de integração para enfrentar o problema dos desastres. Aspectos de Cooperação Sul-Sul são apresentados como um plano preliminar chave para as regiões América do Sul e Ásia-Pacífico, à fim de gerar capacitação e espertise nas áreas de Ciências de riscos e gestão e redução de desastres na América do Sul, América Latina e Caribe.

Palavras-chave: Desastres, Cooperação Internacional Sul - Sul.

\begin{abstract}
Disaster risk management and reduction policy, the intergovernmental policy and strategies mainstream initiatives in the South America and Latin America and Caribbean regions are actually strongly progressing. The regions embraces all the initiatives improved during the last century and decisively advances to create integration mechanisms and resources to address
\end{abstract}

\footnotetext{
${ }^{1}$ Applied Telecommunications Electrical Engineer Master. Expertise in Information Society Technology: Science and Technology Policy Management. Had beeen working during 20 years with public and private corporations on planning and management of engineering projects in Brazil, Africa and South America. Actualy works as Senior Analyst of Science and Technology of the National Council of Technological and Scientific Development CNPq. He served as Executive Coordinator of the CNPq/UNDP International Cooperation Project for the Brazilian Information Society. Collaborator with the Brazilian Commission for Communications CBC-4 from ANATEL, with the Study Group 3 - "Information and communication infrastructure and technology development, emergency telecommunications and climate change adaptation”. E-mail: rborgo@cnpq.br; rlbaquarius@gmail.com
} 
the problem of disasters. South-South cooperation is presented as a key proposal plan for South America and Asia-Pacific Regions to generate capacity building and espertise in the fields of Sciences of risks and disaster management and disaster reduction in South America, Latin America and the Caribbean regions.

Key Words: Disaster, South-South International Cooperation.

RESUMEN: La gestión y la reducción del riesgo de desastres, las políticas, estrategias e iniciativas políticas tradicionales intergubernamentales en América del Sur y América Latina y el Caribe están realmente progresando fuertemente. Las Regiones abarcan todas las iniciativas implementadas durante el último siglo y con decisión se mueven hacia adelante para crear mecanismos e integración de los recursos para hacer frente al problema de los desastres. Aspectos de Cooperación Sur-Sur se presentan como un plan preliminar clave para las regiones de América del Sur y Asia-Pacífico, con el propósito de generar capacidad y espertise en las áreas de Ciencias de riesgos y la gestión y reducción de desastres en América del Sur, América Latina y el Caribe.

\section{Palabras clave: Desastres, Cooperación Internacional Sur - Sur.}

\section{1- Disaster Risks Management and Reduction background View}

Looking for the $\mathrm{XX}$ to $\mathrm{XXI}$ century frontier the big race to face the challenges of global changes have forced the natural hazard and disaster risk's research scientific communities (ICSU 2013, ICSU 2015, IPO/RADI/CAS 2014) improve converging efforts trough intergovernmental policy initiatives pushing international cooperation mechanisms to optimize and support Disaster Risk Management and Reduction (UNISDR, III WCDRR 2015). The Hyogo UN International Strategy to Disaster Reduction (UNISDR) grows from 2005 to face disasters rising scale mainly caused by natural hazards, based on the role of international, national and local resilience generation's framework improvement. The growing escalation of disaster losses and the rush to disaster reduction founded a new odyssey of mankind about adaptation in the XXI century. It completely defies political and sociological rhetoric grounded in the old "business as usual" paradigm of sustainable development and globalization of markets, and it challenges governments and economic blocs, political blocs and unions of nations around resilience generation to match adaptation with disaster risk reduction in an austere search for sustainability (Borgo, Silva 2015). 
The traditional reference in disaster reduction matters actually evolved from Hyogo/Japan Framework for Disaster Risk Reduction (UNISDR HFA 2005) to Sendai/Japan Framework 2015-2030 (UNISDR, III WCDRR 2015) as a global benchmark for the area, putting the issue of cooperation at the center of initiatives, agreements, mechanisms and structural arrangements for development:

"International, regional, sub regional and transboundary cooperation remains pivotal in supporting the efforts of States, their national and local authorities as well as communities and businesses to reduce disaster risk.";

"Each State has the primary responsibility to prevent and reduce disaster risk, including through international, regional, sub regional, transboundary and bilateral cooperation. The reduction of disaster risk is a common concern for all States and the extent to which developing countries are able to effectively enhance and implement national disaster risk reduction policies and measures in the context of their respective circumstances and capabilities can be further enhanced through the provision of sustainable international cooperation ";(author griffins)

\section{2- Introduction and Motivations:}

Considering advances supported by Latin America and Caribbean (LAC) regional organizations for management and disaster reduction especially in the early decades of the twenty-first century, in addition to the UNISDR the Americas initiatives to the region, mmajor national efforts have been promoted and framework planning studies emerged to face the challenges of the global changes by the countries of the Latin America Caribbean region, which includes Central America, the Caribbean and South America (Brugnoni 2015), to develop their national and local security and disaster risk management and reduction integrated platforms, systems and networks (Borgo 2015). An Latin American integrated regional strategic positioning for disaster reduction and management in the twenty-first century it started from 2015 promoted by intergovernmental policy blocks major force driving work plans for the short (2015) and medium (2022) terms, in the context of regional integration of the Latin American and Caribbean States Community (CELAC) (CELAC 2015) and the Union of South American Nations (UNASUR) (UNASUR 2014).

\section{1- About the UNASUR Risk Management Plan}

The theme natural and anthropical disasters had been incorporated in the UNASUR government constitution trough seven sector's councils where they set priorities 
on: biodiversity ecosystems, hydro resources protection and conservation, the regional cooperation for catastrophes prevention, considering the abrupt weather changes and climate variability. As a matter of planning it was created a UNASUR high level task force group for integral disaster risk management (GTAN-GRD). Their document "Considerations to strengthen a South American strategy for reducing disaster risks" The UNASUR Action Plan for Integral Disaster Risk Management" set the "Strategic Objectives and Action Lines" and foresee the intergovernmental cooperation and solidarity in the way to get disaster risk reduction governance in the South America region. We quote (Brugnoni 2015, page 27):

- "Strategic Objectives:

A - Improve Institutional efforts for Integral Disaster Risk Management trough Regional, National and Local cooperation and expertise exchange.

B - Improve Integral Disaster Risk Management capacity building based on S\&T applied to disaster prevention.

C - Improve Information Systems to support scientific research networks.

$D$ - Better improve assessment and risk monitoring, early warning and forecast plans to full support disaster prevention."

- “Action Lines

A- Regional Agenda for Integral Disaster Risk Management research and development.

$B$ - Capacity building generation and improvement on Integral Disaster Risk Management for expertise networking in the UNASUR council's liability and compliance.

C- Promotion of South-South and Triangular cooperation mechanisms for Integral Disaster Risk Management Plan.

D- Promotion of Regional integral Disaster Risk Management Framework joint efforts with the humanitarian assistance mainstream on the region.

E - Improve an Integrated Regional Emergency Information System."

\section{2- Estimates and Prospects for Implementation of a Disaster Management and risk reduction dedicated and integrated Scientific and Technological Platform in LAC region.}

This item refers to the Emergency Information System technological infrastructure to cover the UNASUR Plan for Integral Disaster Risk Reduction and Management Action Lines (Brugnoni 2015).

As a matter of geo information, the LAC region is situated on the sub region 02 of the Radio communication section of the International Telecommunication Union (ITU-R) map 
illustrated in Figure 1.3. As an example of the actions already implemented in the others regions: 01(UE) and 03 (Asia Pacific), and 02 (North America) of the ITU-R.

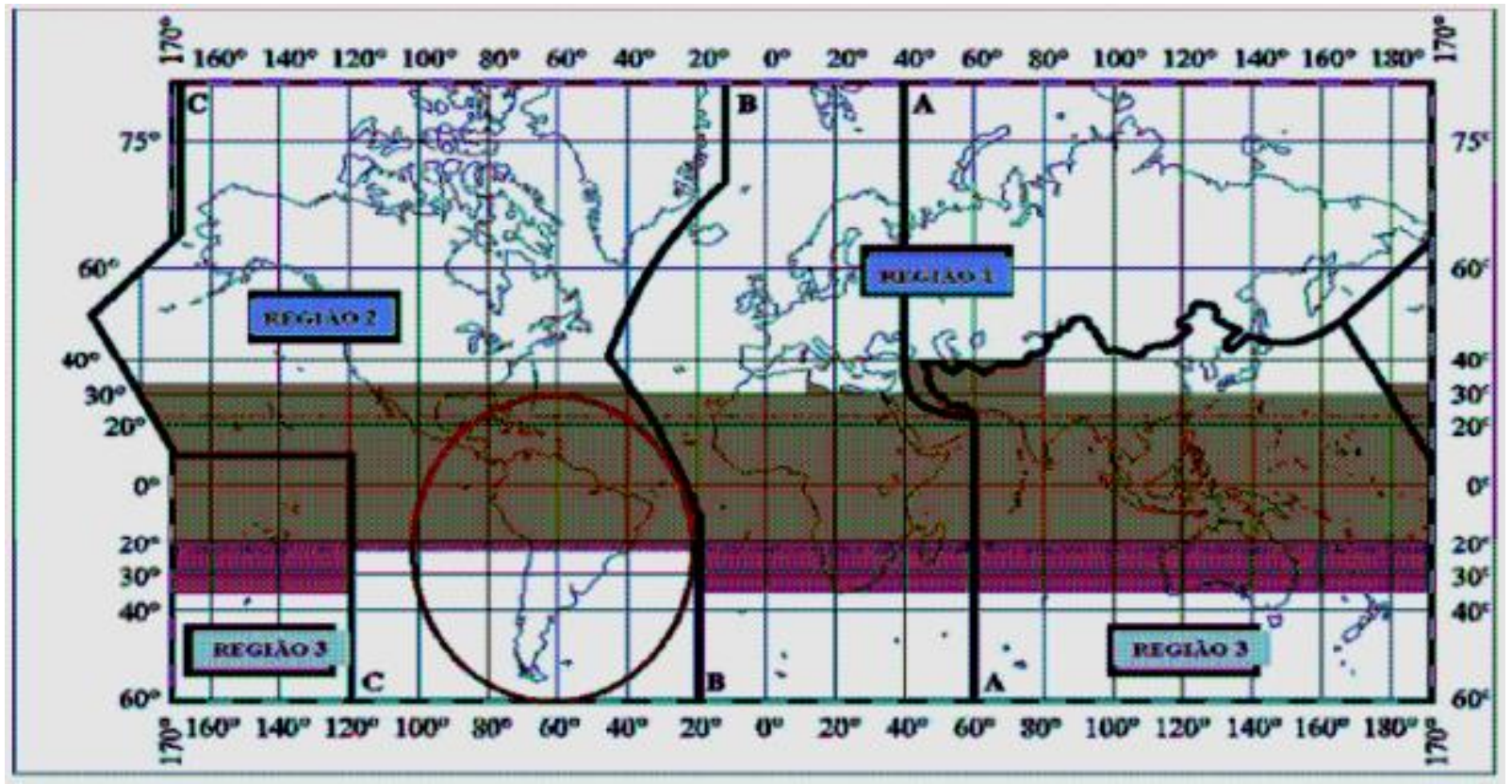

Figure 1: The World ITU-R map of telecommunication sub-regions. Source: (Borgo 2013)

Actually the region has no dedicated and integrated technical platform holding full support for management and disaster risk reduction framework and it is understood as the $2^{\text {nd }}$ region of the world hardest hit by hydro meteorological disasters with economic losses of around $1 \%$ of GDP. The LAC region Science and Technology cooperative framework Police Initiative to project and construct a dedicated and integrated Scientific and Technological Platform applied to disaster risk reduction and management, it is estimated margin range nearly around $10 \%$ to $20 \%$ of the annual economic losses( $\mathrm{R} \$$ tens of billions ) due to disasters in the region (Borgo 2013).

The infrastructure integration agreements for development of the Union of South American Nations (UNASUR) and the Community of Latin American and Caribbean States (CELAC), they could promote in the near future (2020/2025), an integrated and dedicated regional technical platform based on Information and broadband Communication technological infrastructure to support full cycle disaster risk reduction and management (Borgo 2015).

The terrestrial segment could be composed of national disaster management stations and local centers as nodes of the disaster management network, and the space segment composed by a multi- 
satellite constellation for shared and cooperative multiple uses. The shared applications, shall cover since teaching and learning, environmental monitoring and management, research, development and scientific- technological innovation, public protection, disaster risk reduction and recovery to human safety and health.

The Asia - Pacific region situated on the sub-region 03 of ITU-R, improved its own framework "SENTINEL ASIA" which offers a huge experience on information and communication systems to support full management and disaster reduction in the region (Kaku et. al. 2013). Especially for the second sub-region comprising Latin America and Caribbean, the development model can start with a pilot program for an integrated South America regional platform from Brazil (Borgo 2015).

\section{3- About a Proposal International South-South Cooperation plan between the Regions South America and Asia-Pacific.}

\section{1- Main Strategic Plan Objective:}

To Promote the Establishment of an South-South Cooperation Agreement between South America and Asia-Pacific to promote a Key Institute of Science and Technology for Disaster Management and Reduction R\&D. The Agreement could be extended to the LAC region, as a joint venture international cooperation framework in the context of the BRICS economic block of nations ${ }^{2}$ with the countries of the Asia-Pacific region, which holds the major expertise in this area of scientific and technological knowledge.

\section{2- Specific Objectives of the Institute}

3.2.1- Promote general capacity building and system's facilities for the LAC region government's technical-scientific staff coordination's to improve their National's framework planning and full capacity building, considering the Union of South American Nations 
(UNASUR) disaster reduction strategy (UNASUR/COSIPLAN 2012), and the Community of Latin America and Caribbean States (CELAC) Action Plan 2015 (CELAC 2015).

3.2.2- Promote an international cooperation umbrella agreement with the Tsinghua University and the Natural University of Beijing networks, the National Disaster Reduction Center of China (NDRCC), the Asia-Pacific Space Cooperation Organization (APSCO), the Asia Disaster Reduction Center (ADRC), the Asia-Pacific Space Agency Forum (APRSAF), the Asia and Pacific Centre for Transfer of Technology (APCTT) and other partners organizations, to promote planning of the Key Institute.

3.2.3- Promote the National Platforms cooperative project development and the LAC regional integrated network to full support Disaster Management and Reduction in the XXI century, in the medium term 2025.

\section{3- The Institute Plan Governance:}

It's much desirable as a matter of agreement to face the BRICS Bank ${ }^{3}$ holding the Plan execution following the UNASUR South America Strategy for Disaster risk reduction ( UNASUR/COSIPLAN 2012), the UNASUR Task Force Group for the Disaster Risk Management and Reduction (GTAN-GRD) Action Plan (Brugnoni 2015) and the CELAC Action Plan 2015 (CELAC 2015).

\section{4- Perspective of Time Schedule:}

- Understandings between Regions/Governments: December 2015.

- Submission of the Plan to the UNASUR: Jan. 2016.

- Planning, Design and Deployment: July 2016.

- Home Activities: July 2016.

\section{5 - Perspectives on Location: Brasília/Brazil}




\section{End Notes}

1- MSc. in Telecommunication Electrical Engineer at the University of Brasília(UNB/BR). S\&T Senior Analyst at the National Council for Scientific and Technological Development CNPq (2003-2015). Executive Coordinator of the CNPq/UNDP Brazilian National Information Society Technologies Project (2003-2007). Telecommunication engineer at TELEBRÁS (1989- 1996). International Cooperation Engineer for Mozambique Ministry of Industry and Energy State Company (1980-1986). Emails: rlbaquarius@gmail.com; ronaldo.borgo@cnpq.br Affiliation: Brazil’s National Council for Scientific and Technological Development CNPq.(Http:II www.cnpq.br)

${ }^{2}$ The emerging economies of Brazil, Russia, India, China, and South Africa - the BRICS - have been touted as the leaders of the developing world. http://carnegietsinghua.org/2014/12/01/limitsof-cooperation-among-brics-countries

3. The New Development Bank BRICS (NDB BRICS), formerly referred to as the BRICS Development Bank, is multilateral development bank operated by the BRICS states (Brazil, Russia, India, China and South Africa) as an alternative to the existing US-dominated World Bank and International Monetary Fund. http://ndbbrics.org/

\section{References}

Borgo, R. L. 2013. About the extreme climate changes adaptation and disaster risks management and reduction in the Latin America ad Caribbean Region. DOI: 10.5216/teri.v3i1.27319 TERCEIRO INCLUÍDO ISSN 2237-079X NUPEAT-IESA-UFG, v.3, n.1, Jan./Jun., 2013, p. 37-46, Artigo 36. www.revistas.ufg.br/index.php/teri/article/download/27319/15466

Borgo, R. L. 2015. Toward an XXI century integrated technological framework to support disaster management and reduction in the Latin America and Caribbean LAC region. TERCEIRO INCLUÍDO ISSN 2237-079X NUPEAT-IESA-UFG, v.4, n.2, Jul../Dez., 2014, p. 209-218, Artigo 77. www.revistas.ufg.br/index.php/teri/article/download/35277/18487.

Borgo, R.L. and Silva, D.H. da .2015. Disaster Risk Reduction. UNISDR 2014 Regional Conferences and the S\&T International cooperation perspectives. (Redução de Riscos de Desastres. As Reuniões regionais da UNISDR em 204 e as perspectivas de Cooperação Internacional). DOI: 10.5216/teri.v4i1.33945 . Published June 2015 at Terceiro Incluido journal, ISSN 2237-079X NUPEAT-IESA-UFG, v.4, n.1, Jan. /Jun., 2014, p. 83-96, Artigo 55. www.revistas.ufg.br/index.php/teri/article/download/33945/17961

Brugnoni Pablo, 2015. Considerations for Strengthening an South America Strategy for Disaster Risk Reduction (Consideraciones para Fortalecer una Estrategia Suramericana para la Reduccíon del Riesgo de Desastres). Task Force Group for Disaster Management and reduction. 
.UNASUR. Montevideo, febrero 2015.

CELAC Action Plan 2015- INTERNATIONAL HUMANITARIAN ASSISTANCE IN CASES OF DISASTER. III Cumbre CELAC Costa Rica 2015.

ICSU (International Council for Science). 2013. Integrated Research on Disaster Risk IRDR Strategic Plan 2013-2017.

ICSU (International Council for Science)-ISSC AD-HOC GROUP ON DISASTER RISK ASSESSMENT. 2015. Disaster Risks Research and Assessment to Promote Risk Reduction and Management. March 12, 2015. Paris: ICSU.

IPO/RADI/Chinese Academy of Sciences (CAS). 2014. IRDR (Integrated Research on Disaster Risk)-Annual-Report-2014. Addressing the challenges of natural \& human-induced environmental hazards. Beijing, China. www.irdrinternational.org

Kaku K., Held A. 2013. Sentinel Asia: A Space- based Disaster Management support system in the Asia-Pacific region. International journal of disaster risk reduction 6 (2013) $1-17$. ELSEVIER.

Peijun, Shi. Jaeger, C. and Qian, Y. 2013. Integrated Risk Governance. Science Plan and Case Studies of Large-scale Disasters. Beijing Normal University Press \& Springer. IHDP-Integrated Risk Governance Project Series

Wisner Ben, Gaillard J.C., Kelman Ilan. 2012. Handbook of Hazards and Disaster Risk Reduction and Management. Routledge Handbooks. Routledge Edithors

UNASUL/IIRSA/COSIPLAN, 2014. Disaster risk management on COSIPLAN/IIRSA infrastructure integration. 2015 User manual. Guidelines for undertaking risk analysis. Version for piloting use in 2015. (Gestión de riesgo de desastres en la infraestructura de integración de COSIPLAN/IIRSA. Manual de Usuario. Orientaciones para emprender análisis de riesgo. Versión para ser usada en pilotaje 2015). Uruguai, Montevideo, novembro 2014. http://www.iirsa.org/admin_iirsa_web/Uploads/Documents/rcco10_montevideo14_plan_de_traba jo_2015_final_Eng.pdf

UNASUR/COSIPLAN, 2012. Strategic Plan of action 2012-2022. (PLAN DE ACCIÓN ESTRATÉGICO 2012-2022). CONSEJO SURAMERICANO DE INFRAESTRUCTURA Y PLANEAMIENTO (COSIPLAN). www.iirsa.org/admin.../rc_brasilia11_1_pae.pdf

UNISDR (United Nations International Strategy for Disaster Reduction). 2015. III World Conference on Disaster Risk Reduction (WCDRR). Sendai Framework for Disaster Risk Reduction 2015-2030. Sendai, Japan, 18 March 2015 